\title{
Potential of Tourism Development in the Republic of Tatarstan
}

Bagautdinova N.G.

Chernov E.E.

Pudovik E.M.

Pratchenko O.V.

Kazan Federal University, Institute of Management, Economics and Finance, Kazan, 420008, Russia

Kazan Federal University, Institute of Language, 420008, Kazan, Russia

Email: epudovic@mail.ru

\section{Doi:10.5901/mjss.2014.v5n28p45}

\section{Abstract}

At the present time the creation of favorable conditions for the development of international tourism is set out as one of the main priority tasks for the normal functioning of the tourism business in the Russian Federation and the Republic of Tatarstan. International practice shows that in modern conditions the international tourism - as the form of international economic relations - was considerably developed and started to have significant influence on political, economic and cultural ties between the countries. In its turn, this leads to the increase of budget and to improvement of life of some regions of the country.

Keywords: tourism, Universiade - 2013, financing, programs of tourism development in the Republic of Tatarstan, tourist flow

\section{Introduction}

Tourism is one of the largest and most dynamic sectors of the economy. High rates of economic growth, large amount of currency earnings greatly affect different sectors of the economy; it promotes the formation of their own tourist industry. According to the UN estimates, $9 \%$ of the world GDP, $11 \%$ of global consumption spending falls to the tourism industry. Thus, at present we cannot fail to notice the great influence of the tourism industry on the global economy. [8]

In many countries of the world tourism is developing as a system that provides all possibilities for acquaintance with history, culture, traditions, spiritual and religious values of the country and its people $[1,2]$.

Tourism brings profit to the state budget, as well as to many natural and legal persons who are - some way or other - connected with the provision of tourist services. Besides the significant item of income, tourism is also one of powerful factors of strengthening of the country prestige, the increase of its significance in the eyes of the international community and ordinary citizens [5]. Besides the significant items of income, tourism is also a powerful factor strengthening the prestige of the country, the growth of its value in the eyes of the international community and ordinary citizens $[6,10]$.

According to the World Tourism Organization, more than 250 million people work in the tourism sector. Tourism greatly influences the key sectors of the economy, such as transport, communications, trade, construction, agriculture, production of commodities and many others, acting as the catalyst of socio-economic development. And in this regard, the study of tourism development in the Russian Federation is one of the topical problems [7].

\section{General Characteristics of the Tourism Potential of the Republic of Tatarstan}

The tourism potential of the Republic of Tatarstan is huge: good geographic location of the rivers Volga and Kama, scenic lakes, forest areas, historical and memorial sites, unique traditions of two great cultures, Tatarstan is one of the largest regions of Russia in terms of population and economic potential. It takes one of the first places in the country in value of the Gross Regional Product, and in the standard of living of the population. There are 7000 objects of cultural value, 82 attractions of ecological tourism, sources of mineral water and therapeutic muds in the republic. In the Republic of Tatarstan a lot is done for the development of tourism: Tatarstan is one of the first regions in Russia that developed its own program of tourism development. We see its implementation in the process of improving the transport and hotel 
infrastructure, in the appearance of new interesting tourist routes in the republic. The celebration of the millenium anniversary of Kazan, the recent Universiade, the expected world-class sporting events such as the 2015 World Aquatics Championships and the 2018 FIFA World Cup became a powerful spur for the activation of tourism. Thanks to this policy, Kazan changed and greatly enhanced its attractiveness. Tourism development state authority is very necessary not only to the Republic of Tatarstan, but to Russia as well [9].

As a consequence of the development of tourism in the Republic of Tatarstan, the Tatarstan government made the decision to establish the agency of the tourism business development. The President of the Republic of Tatarstan Rustam Minnikhanov has already given the appropriate order at the board meeting of the Ministry of Culture of the Republic of Tatarstan. According to him, it should become an important direction of their work.

The tourist area is underdeveloped, and there are not enough considered forms of work with tourists and options for the year-round use of the tourist attractions of Bulgar and Sviyazhsk. And exactly such agency is able to fill the necessary gaps and to make tourism in the Republic of Tatarstan more interesting, unique in its kind due to the historical and cultural potential of the republic. Moreover, it will promote the development of the other areas, in particular, the development of transport, hotel business [3, 4].

\section{The Directions of Tourism Development in the Region}

After the last year's Universiade there was the decline of tourism in the Republic of Tatarstan. However, in comparison to the previous years, in 2013 there was positive dynamics of development of tourist activity in the republic: last year the total number of tourists was 19\% more than in 2012. At the moment there are about 600 tourism organizations and more than 70 tour operators and 130 hotels on the territory of the republic. But it is necessary to consolidate this progress in the field of tourism, secure and to reach the next higher-quality level.

Analysis of indicators of tourism development in the republic shows stable positive dynamics. So, in 2010-2012 the average increment of general tourist flow was 14.8\%, and for the 9 months of 2013 the tourist flow in the Republic of Tatarstan increased by 19\%. For the above-mentioned period the volume of paid travel services in Tatarstan increased by 19.7\%: 6.2 billion robles for the current one and a half years (6.9 billion rubles in 2012). Here sightseeing, hotel and spa services are taken into account. It should be noted that this figure does not include any additional costs of tourists, such as food, transportation, entertainment. In 2013 the budget for the marketing of tourism in the Republic of Tatarstan was 15 million rubles. Among the Russian million-plus cities Kazan also takes the third place in terms of the number of hotels, it is 6100 rooms.

Also the subprogram "Development of tourism and hospitality in the Republic of Tatarstan for 2014 - 2020" was developed, its main aim is to increase the competitiveness of the tourism industry of the Republic of Tatarstan in the Russian and international tourist markets (Figure 1).

This program includes five main tasks that must be performed:

1. Creation of a favorable tourist image of the Republic of Tatarstan, the increase of volume and diversity of offered tourist services for population.

2. The development of tourist and recreational complex of the Republic of Tatarstan.

3. Formation of competitive tourist product and its promotion on prospective tourist markets.

4. Improvement of quality of the national tourist product, the level of hospitality in servicing the tourists at the sites of the tourism industry, with the account of the current domestic and international standards.

5. Improvement of the state policy in the field of tourism and hospitality.

In terms of the dynamics of development the tourist industry of the region takes the leading position in Russia (Fig.

2). 
Fig 1. Financing of the program "Development of the sphere of tourism and hospitality in the Republic of Tatarstan for 2014-2020"

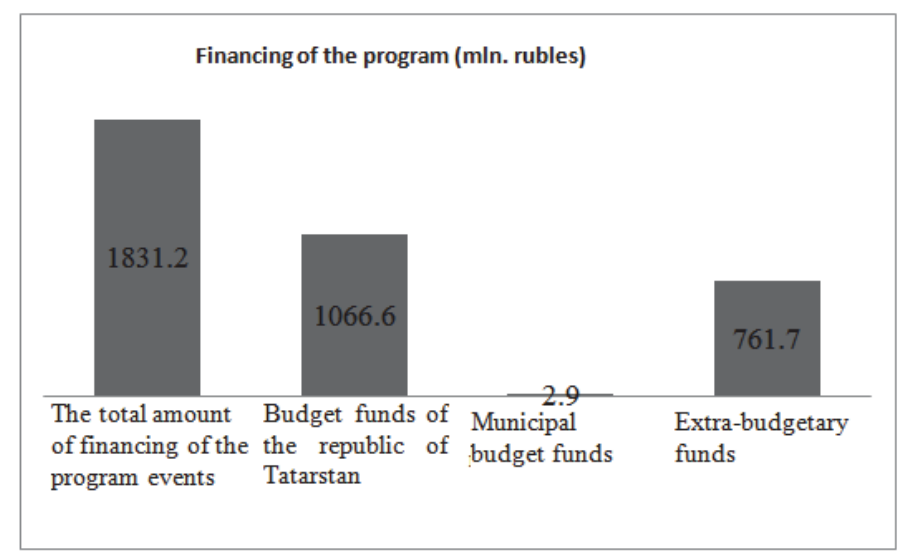

Made on materials of the State Committee of Tourism of the Republic of Tatarstan (http://tourism.tatarstan.ru/rus/index.htm/news/323821.htm)

The studies showed: over the last 5 years the average annual growth of domestic tourist flow was $12 \%$, and even in the crisis period the domestic tourism has grown by more than $5 \%$.

By the number of tourists served the republic is the leader in the Volga Federal District $-25 \%$ of the total flow.

Such high rates were greatly determined by the 2013 summer Universiade. New hotels were built, the network of Catering (opening of restaurants) and transport infrastructure were developed. The appearance of many sports facilities is the most important thing. People all over the world have learnt about Tatarstan, and this gives the full right to assume that in the near future the republic will become popular among tourists as well as the European countries.

Fig 2. Number of employees in the tourist companies of the Republic of Tatarstan, people

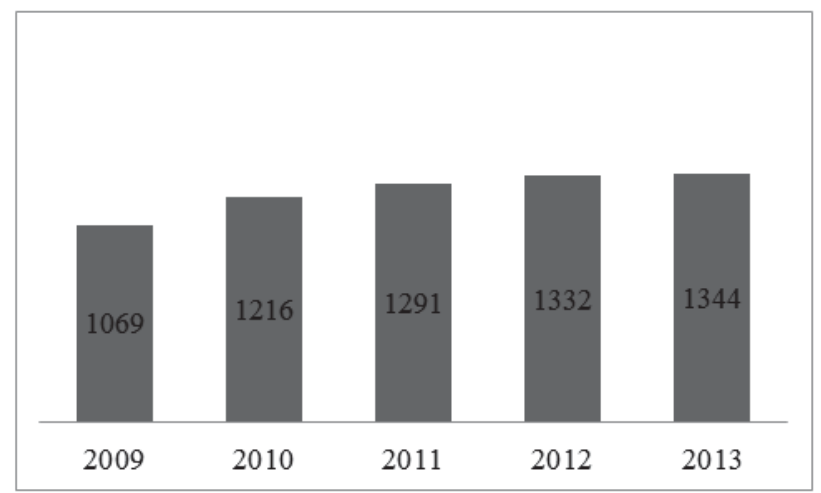

Made on materials of the Ministry of Culture of the Russian Federation of the Federal Tourism Agency (http://www.russiatourism.ru http://www.russiatourism.ru/upload/iblock/48f/chis__rabotnikov_turfirm_2009_2013.doc)

\section{Results}

Tatarstan is an ideal region for the development of different types of tourism, and there are a number of reasons for it.

Firstly, the republic has a favorable economic location and good transport accessibility. One can arrive to the citymetropolis Kazan by plane, by train or by bus, to liner or by ship.

Second, a large number of events, national holidays, such as Sabantuy, conferences, festivals and sports competitions of different levels, are held throughout the entire territory of Tatarstan,. Such events - with good provision of information - are able to attract travelers from all over the world. 
It is also necessary to say about the active position and interest of Tatarstan leadership in the development and implementation of the tourist industry.

However, it is obvious that the tourist potential of the republic is not used to the full, and creation of conditions for quality recreation on the territory of Tatarstan of foreign and Russian citizens requires the more active public policy in the field of tourism. Along with the above-mentioned advantages of the region, there are a number of problems which are characteristic for the current situation of tourism sphere of the Republic of Tatarstan.

Firstly, the insufficient information awareness about Tatarstan, the lack of special tourist information in the streets or other public places, and, of course, the weak representation of the republican tourist product in the global network the Internet is the main drawback.

Insufficient competitiveness of the republican tourist product is the second major problem. The important QualityPrice Ration does not meet international accepted standards. Tourists sometimes claim: for such fee we expected to see much more.

It is also necessary to say about the above-mentioned underfunding of the industry.

It is also necessary to identify the main obstacles, the overcoming of which is essential for the industry. For example, historical and cultural monuments attract the most attention of tourists. Until recently, Kazan was one of the five major Russian cities that preserved its historical look. Now, dozens of old buildings, including historic and cultural monuments, are wrecked, and more buildings are in critical state.

Adoption of the program of conservation and development of the historical and cultural heritage of Tatarstan is the urgent problem of city and national authorities. For example, the establishment of the social Council of history of the city of Kazan with the right to vote in decisions on demolition or change of the appearance of old buildings could be the necessary measure.

After perfectly held Universiade in summer 2013 the authorities of Tatarstan seriously gave thought to the question: how to maintain the interest of tourists to the republic. The authorities of the region realized that today this area is very popular and, most importantly, profitable [11]. Actions were not to be late in coming (see Table 1).

Table 1. Selected indicators of activity of collective accommodation facilities from 2009 to 2012

\begin{tabular}{|c|c|c|c|c|}
\hline $\begin{array}{c}\text { Republic of } \\
\text { Tatarstan, } \\
\text { year }\end{array}$ & $\begin{array}{c}\text { Number of hotels and } \\
\text { similar accommodation } \\
\text { means }\end{array}$ & $\begin{array}{c}\text { Number of nights in hotels } \\
\text { and similar accommodation } \\
\text { means, thousands }\end{array}$ & $\begin{array}{c}\text { Number of accommodated } \\
\text { people in collective } \\
\text { accommodation means, } \\
\text { thousand persons }\end{array}$ & $\begin{array}{c}\text { Amount of paid services of } \\
\text { hotels and similar } \\
\text { accommodation means, bln. } \\
\text { rubles }\end{array}$ \\
\hline 2012 & 217 & 1893,6 & 1430,5 & 3,4 \\
\hline 2011 & 188 & 1445,8 & 1113,5 & 2654,8 \\
\hline 2010 & 188 & 1445,8 & 1113,5 & 1991 \\
\hline 2009 & 163 & 1354 & 989,1 & 1932,3 \\
\hline
\end{tabular}

Made on materials of the Ministry of Culture of the Russian Federation of the Federal Tourism Agency (http://www.russiatourism.ru http://www.russiatourism.ru/content/8/section/81/detail/4124/)

Long-term cooperation with the Austrian consulting company Kohl\&Partner is the major step towards the development of tourism in Tatarstan. In 2011 the project Manager Christopher Martin Hinteregger came to our region, and already at that moment he had already had a specific purpose - to develop the master-plan of the development of tourism of the Republic and promotion of rich tourist resources on the promising Russian, and, most importantly, foreign markets. Immediately after the Universiade the company, having assured in unchallenged success of the future project, started its implementation.

The main obstacles that interfere the development of tourism in the Republic of Tatarstan, were identified. Firstly, in Russia, as well as abroad people know very little about the tourist attractiveness of Kazan. Secondly, in Tatarstan there are very few developed tourist sightseeing attractions outside the capital. Thirdly, there is no clear and strong tourism brand of Tatarstan and Kazan. Fourth, the distance between various tourist facilities of the Republic of Tatarstan is too great.

After the Summer Youth Games held in July 2013 Kazan got the name "Third Capital of Russia". It is necessary to say that dozens of major international sport events - world and European championships, pre-Olympic tournaments, etc. - were held in the republic at high level. No doubt, all this contributed to the active inflow of both Russian and foreign tourists to Kazan. 
Thus, sport events contribute to the general awareness of Tatarstan on the international arena. Qualitative and modern high-tech sports facilities and historic sites are able and have already become a driver for attracting the tourists to the Republic of Tatarstan.

\section{References}

Abankina, T. Regional development models using cultural heritage resources.(2013) International Journal of Culture, Tourism, and Hospitality Research, 7 (1), pp. 3-10.

Chen, B., Sevastyanov, D.V. Formation, contemporary state and the prospects for the development of international tourism in China and Russia (2010) Vestnik Sankt-Peterburgskogo Universiteta, Seriya Geologiya i Geografiya, 2010 (1), pp. 100-108.

Doronkina, I., Borisova, O. Ecotourism in community environment (2014) World Applied Sciences Journal. - Vol.-30.- Issue 30.- Pages 35-36

Ermakov, S.A., Ilkevich, S.V., Ermakov, A.S. Information resources strategy in the promotion of Russia's rural tourism attractions (2014). World Applied Sciences Journal .-Vol. 30. - Issue 30. - Pages 91-92

Kate Appleton, Rich Beattie, Adrien Glover, Lyndsey Matthews, April Orcutt, Joshua Pramis, Ann Shields World's Most-Visited Tourist Attractions // Travel+ Leisure, 2014 pp. 32-46.

Kramin, T.V., Safiullin, L.N., Timiryasova, A.V. Defining priorities of management of investment attractiveness of the region and their consideration in the framework of implementing large sports events (2014) Mediterranean Journal of Social Sciences, 5 (18 SPEC. ISSUE), pp. 275-282.

Oborin, M., Tryastsin, M. Medical and health tourism in Russia: Some economic development features (2014) Life Science Journal. Volume 11, Issue SPEC. ISSUE 8, 2014, Article number 95, Pages 430-432

Prokkola, E.-K. Regionalization, Tourism Development and Partnership: The European Union's North Calotte Sub-programme of INTERREG III A North (2011) Tourism Geographies, 13 (4), pp. 507-530.

Saprunova, V. Small business in the tourism and hospitality industry of Russia (2006) Tourism in the New Europe: Perspectives on SME Policies and Practices, pp. 215-225.

Sharifinia, Z. Analyzing the ranking of security challenges of tourism development: A case study of Mazandaran Province, Iran (2015) Theory and Practice in Hospitality and Tourism Research - Proceedings of the 2nd International Hospitality and Tourism Conference 2014, pp. 567-572.

The Republic of Tatarstan: guide to investment // ttp://tida.tatarstan.ru/file/Invest_guide_eng\%281\%29.pdf.

Razumovskaya, E.M.,Mishakin, T.S., Popov, M.L., Kucevol, N.G. Medical services during the XXVII world summer universiade 2013 in Kazan. Mediterranean Journal of Social Sciences vol. 5 (18 SPEC. ISSUE), pp. 17-20

Arustamyan, G.,Yegorov, E., Lipsky, S.,Razumovskaya, E.,Gimranova, L. Clinical and economic analysis and its role in healthcare quality management. World Applied Sciences Journal vol. 27 (3), pp. 318-323.

Derevenskaia Olga. Active learning methods in environmental education of students. Procedia - Social and Behavioral Sciences Vol. 131, pp. 101-104 // 3rd World conference on educational technology researches Turkey 07-09.11.2013. 